\title{
The grass is always greener on the other side: Triplectides Kolenati, 1859 (Leptoceridae) and Marilia Müller, 1880 (Odontoceridae) occupying cases of other Trichoptera species
}

A grama é sempre mais verde do outro lado: Triplectides Kolenati, 1859 (Leptoceridae) e Marilia Müller, 1880 (Odontoceridae) ocupando casulos de outras espécies de Trichoptera

\section{Lucas Marques de Camargos and Ana Maria Oliveira Pes}

Laboratório de Taxonomia e Biologia de Trichoptera e Ephemeroptera,

Coordenação de Pesquisas em Entomologia - CPEN, Instituto Nacional de Pesquisas da Amazônia - INPA, Petrópolis, CP 478, CEP 69010-970, Manaus, AM, Brazil e-mail:1mcamargosbio@gmail.com; anampes@gmail.com

\begin{abstract}
Aim: Larvae of Triplectides spp. and Marilia sp. occupying cases of other species are recorded and photographed; Methods: The material was collected in different sites and dates in Atlantic Forest and Central Amazon regions; Results: The Triplectides larvae seem to have an opportunistic behavior, occupying a great variety of cases, which reflects their common habit of enter in hollow twigs instead of build complex cases. However, this behavior is not frequently recorded in Marilia larvae, and we believe that the difference on the roughness of the interior walls, as well as the difference of the color of the material of the cases limit the opportunistic behavior in this genus; Conclusions: Experimental studies with different species can help the understanding of this behavior in the light of adaptive values.
\end{abstract}

Keywords: opportunistic behavior, case building, biology, Integripalpia, aquatic insects.

Resumo: Objetivo: Larvas de Triplectides spp. e Marilia sp. ocupando casulos de outras espécies são registradas e fotografadas; Métodos: $\mathrm{O}$ material foi coletado em diferentes localidades e datas em regiōes de Mata Atlântica e Amazônia Central; Resultados: As larvas de Triplectides parecem ter um comportamento oportunista, ocupando uma grande variedade de abrigos, o que reflete seu hábito comum de entrar em galhos vazios ao invés de construir casulos complexos. Entretanto, este comportamento não é registrado freqüentemente em larvas de Marilia, e nós acreditamos que a diferença na rugosidade das paredes interiores, assim como a diferença na cor dos tipos de materiais dos casulos limitam o comportamento oportunista entre as espécies deste gênero; Conclusóes: Estudos experimentais com diferentes espécies podem ajudar o entendimento desse comportamento à luz dos valores adaptativos.

Palavras-chave: comportamento oportunista, construção de casulo, biologia, Integripalpia, insetos aquáticos.

The great diversity and the occupation of many aquatic environments by the caddisfly larvae have a significant contribution from the silk production by the labial glands (Mackay and Wiggins, 1979). Different species build cases, retreats and nets for food uptake in distinct forms which reflect its habits (Wiggins, 2004).

The construction of tubular portable cases by the larvae of the suborder Integripalpia represents a different feature that allows its occupation in different niches in relation to other Trichoptera groups, as they can pursuit their food more actively (Wiggins, 2004), gain protection due to camouflage (Nielsen, 1942) and can survive in warm and poor oxygenated environments through an unidirectional water flux within the case (Milne, 1938; Wiggins, 1996; Williams et al., 1987). These cases can be made of different types of material, including great variety of sand grains, tree leaves, small twigs, shells and even silk only (Wiggins, 2004).

It is known that somelarvae of the genus Triplectides occupy empty cases of species of Grumicha Müller, 1879 (Müller, 1878; Flint Junior et al., 1999; CrisciBispo et al., 2004), Parasericostoma Schmid, 1957 (Flint Junior et al., 1999) and Nectopsyche Müller, 1879 (Crisci-Bispo et al., 2004). This invasive behavior is also recorded in a Marilia species (Marilia elongata Martynov, 1912) in the larval 
case of Grumichella Müller 1879. Here we record and illustrate for the first time the opportunistic behavior with Triplectides on larval cases of Marilia, Grumicha and Amazonatolica hamadae Holzenthal and Pes, 2004, and Marilia on Grumicha cases.

The material was collected in different sites of Atlantic Forest and Central Amazon region, Brazil, in different periods as listed below. A D-net as well as hand sleeves were used to collect the larvae in different substrates (Table 1). The specimens were identified with the keys of Pes et al. (2005) and Calor (2007). The larvae were fixed in $100 \%$ alcohol, and are deposited in the Invertebrate Collection of the Instituto Nacional de Pesquisas da Amazônia (INPA).

The Triplectides larvae usually add leaves to the front opening of the occupied case, like Figure 1a, b. This possible occurs when the larva is growing larger than the invaded case. In Figure 1c, there is an evident cut in one side of the case, like they do with a hollow twig (Müller, 1878). In Figure 1d, despite being occupied by a Triplectides sp. larva, the Grumicha sp. case has stones added to the front opening, like the one occupied by a Marilia larva in 1.f. Maybe it was originally invaded by a Marilia sp. larva, and then the Triplectides sp. occupied it after the first invader emerged or get predated. On the amazonian streams, T. egleri Sattler, 1963 up to the third instar usually occupy empty silk cases of Amazonatolica hamadae (Figure 1e), commonly observed on kinon, a biocoenosis drifting along the amazonian rivers in a floating mass of roots, logs, fruits and leaves (Fittkau, 1977).
The fact that the Triplectides larvae do not really build cases, just occupying hollow twigs or burrowing the not yet empty ones (Müller, 1878), may explain this common opportunistic
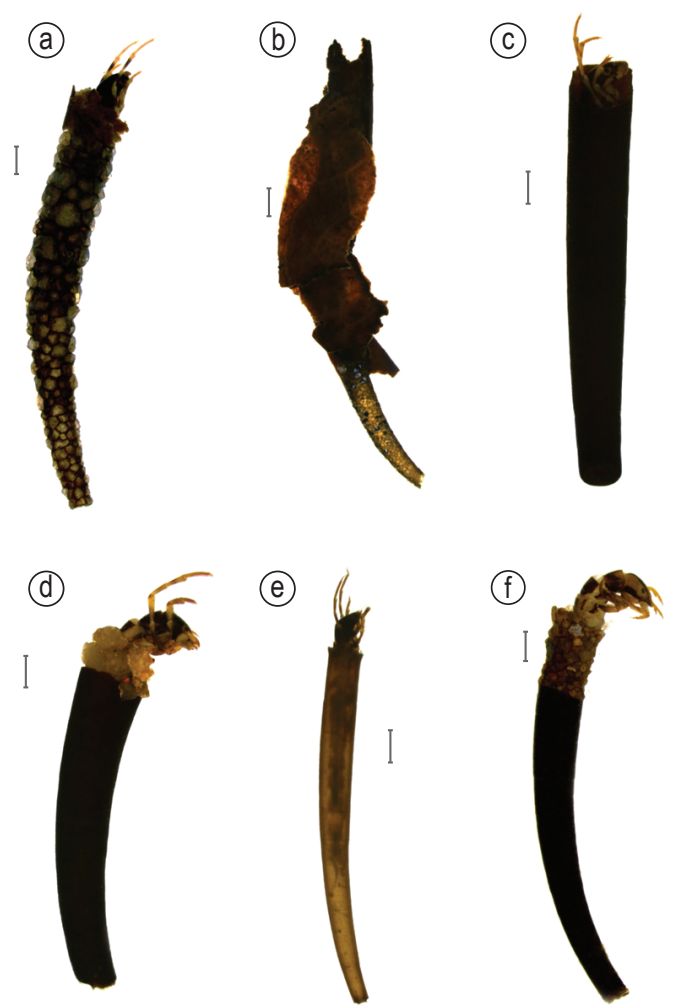

Figure 1. a-b) Triplectides sp. from Quatro Barras and from Rio de Janeiro respectively; in Marilia sp. case c-d) Triplectides sp. from Quatro Barras in Grumicha sp. case; e) Triplectides egleri Manaus in Amazonatolica hamadae case; f) Marilia sp. from Ponte Serrada in Grumicha sp. case. Scale: $1 \mathrm{~mm}$.

Table 1. The different taxa, survey sites and habitats of the caddisflies found on cases of another species.

\begin{tabular}{|c|c|c|c|c|c|c|}
\hline Taxon & Case & Site & Date & Coordinate & Specimens & Habitat \\
\hline Triplectides sp. & Marilia sp. & $\begin{array}{l}\text { Recanto Engenheiro } \\
\text { Lacerda, municipality } \\
\text { of Quatro Barras, PR }\end{array}$ & 11.vii.2011 & $\begin{array}{l}25^{\circ} 20^{\prime} 2.39^{\prime \prime} \mathrm{S} \\
48^{\circ} 54^{\prime} 6.88^{\prime \prime} \mathrm{W}\end{array}$ & 2 & Sand/Pool \\
\hline Triplectides sp. & Marilia sp. & $\begin{array}{c}\text { Paulo e Virgínia } \\
\text { cavem, Rio } \\
\text { Cascatinha, Parque } \\
\text { Nacional da Tijuca, } \\
\text { municipality of Rio de } \\
\text { Janeiro, RJ. }\end{array}$ & 30.vi.2011 & $\begin{array}{l}22^{\circ} 58^{\prime} 12.71 " \mathrm{~S} \\
43^{\circ} 15^{\prime} 25.60^{\prime \prime} \mathrm{W}\end{array}$ & 1 & Sand/Pool \\
\hline Triplectides sp. & Grumicha sp. & $\begin{array}{l}\text { Recanto Engenheiro } \\
\text { Lacerda, municipality } \\
\text { of Quatro Barras, PR }\end{array}$ & 11.vii.2011 & $\begin{array}{l}25^{\circ} 20^{\prime} 2.39^{\prime \prime} \mathrm{S} \\
48^{\circ} 54^{\prime} 6.88^{\prime \prime} \mathrm{W}\end{array}$ & 4 & $\begin{array}{l}\text { Leaves/ } \\
\text { Riffle }\end{array}$ \\
\hline Triplectides egleri & $\begin{array}{c}\text { Amazonatolica } \\
\text { hamadae }\end{array}$ & $\begin{array}{l}\text { Igarapé do Tinga, } \\
\text { Reserva Ducke, } \\
\text { municipality of } \\
\text { Manaus, AM. }\end{array}$ & 8.v.2002 & $\begin{array}{l}02^{\circ} 57^{\prime} 00^{\prime \prime} \mathrm{S} \\
59^{\circ} 57^{\prime} 00^{\prime \prime} \mathrm{W}\end{array}$ & 30 & $\begin{array}{l}\text { Leaves } \\
\text { and roots/ } \\
\text { Riffle }\end{array}$ \\
\hline Marilia sp. & Grumicha sp. & $\begin{array}{l}\text { Rio Irani; BR } 282, \\
\text { Parque dos Butieiros, } \\
\text { municipality of Ponte } \\
\text { Serrada, SC. }\end{array}$ & 04.ix.2009 & $\begin{array}{l}26^{\circ} 55^{\prime} 49.2^{\prime \prime} \mathrm{S} \\
51^{\circ} 52^{\prime} 29.3^{\prime \prime} \mathrm{W}\end{array}$ & 1 & $\begin{array}{l}\text { Roots/ } \\
\text { Riffle }\end{array}$ \\
\hline
\end{tabular}


behavior with various species, since they do not need to build or prepare the case. They simply use a case of resistant material as a camouflage and/or a respiratory device like they naturally do with a twig. The larvae do not invade only empty cases of other Trichoptera species, since some individuals are observed even in body parts of dead arthropods (Figure 2).

On the other hand, the opportunistic behavior of Marilia larvae was recorded (Rueda-Martín, 2008) before this work, and even here it was uncommon. The advantages of using a case already built is the optimization of energy costs, which is somewhat predicted by the optimal foraging theory (MacArthur and Pianka, 1966). Also, cases of Grumicha are as resistant as Marilia cases.

However, some species line the interior wall of the case with silk, to facilitate the undulation movement and prevent the gill abrasion (Williams and Penak, 1980; Okano and Kikuchi, 2009). Other species, like some of Odontoceridae, select particles with at least one smooth surface to cover the interior walls (Okano et al., 2010). This difference between the interior walls of the cases can explain the lack of more evident opportunistic caddisflies in many surveys. Besides that, the different types of material, like the dark silk of Grumicha cases and the stony Marilia cases can disturb the camouflage with the natural substrate of the opportunistic species.

Experimental studies with various species can be done to explain more questions about that behavior. It is possible that some species do not use even an already built case of the same species, while others save time and energy and take the opportunity to enter in any type of cases. These studies may also focus on the adaptive values of the different behavioral strategies.

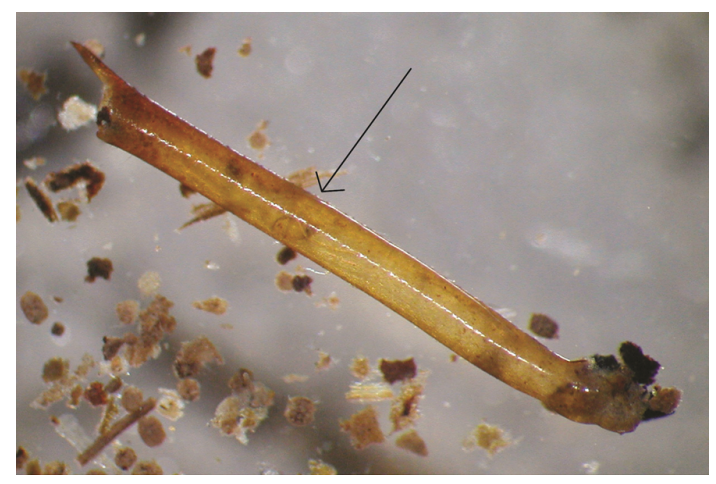

Figure 2. Triplectides egleri from Manaus in a part of a shrimp leg. The head and torax of the larva are visible in the middle portion of the structure, marked by the arrow.

\section{Acknowledgements}

The authors thank Msc. Allan Santos and Dr. Ana Lúcia Oliveira for the help at the Tijuca fieldwork, in Rio de Janeiro, and Msc. Maurício Zenker for the transportation to Recanto Engenheiro Lacerda, in Quatro Barras. We also thank Dr. Victor Lemes Landeiro for the photograph of Triplectides egleri in the shrimp leg and Msc. André Fernandes for reviewing the manuscript. We are very grateful to PROCAD program, which allows the travel to Paraná and Rio de Janeiro states, and to CNPq for the master's grant. This work was funded by PRONEX/CNPq/ FAPEAM and Pró-Equipamentos/CAPES.

\section{References}

CALOR, A. 2007. Trichoptera. In FROEHLICH, CG., coord. Guia on-line de identificação de larvas de insetos aquáticos do Estado de Sáo Paulo. Biota/ Fapesp. Available from: <http://sites.ffclrp.usp.br/ aguadoce/index_trico $>$.

CRISCI-BISPO, VL., BISPO, PC. and FROEHLICH, CG. 2004. Triplectides larvae in empty cases of Nectopsyche (Trichoptera, Leptoceridae) at Parque Estadual Intervales, São Paulo State, Brazil. Revista Brasileira de Entomologia, vol. 48, no. 1, p. 133-134.

FITTKAU, EJ. 1977. Kinal and Kinon, habitat and coenosis of the surface drift as seen in Amazonian running waters. International Journal of Tropical Geology, Geography and Ecology, vol. 1, p. 9-21.

FLINT JUNIOR, O., HOLZENTHAL, RW. and HARRIS, SC. 1999. Catalog of the Neotropical Caddisflies (Insecta: Trichoptera). Colombus: Ohio Biological Survey. 239 p.

MACARTHUR, R. and PIANKA, E. 1966. On optimal use of a patchy environment. The American Naturalist, vol. 100, no. 916, p. 603-609. http://dx.doi. org/10.1086/282454

MACKAY, RJ. and WIGGINS, GB. 1979. Ecological diversity in Trichoptera. Annual Review of Entomology, vol. 24, p. 185-208. http://dx.doi.org/10.1146/ annurev.en.24.010179.001153

MILNE, MJ. 1938. Case-building in Trichoptera as an inherited response to oxygen deficiency. Canadian Entomologist, vol. 70, p. 177-180. http://dx.doi. org/10.4039/Ent70177-9

MÜLLER, F. 1878. Sobre as casas construídas pelas larvas de insectos Trichopteros da província de Santa Catharina. Archivos do Museu Nacional do Rio de Janeiro, vol. 3, p. 99-124.

NIELSEN, A. 1942. Uber die Entwicklung und Biologie der Trichoptera mit besonderer Beriicksichtgung der Quelltrichopteren Himmerlands. Archiv für Hydrobiologie Supplement, vol. 17, p. 266-631. 
OKANO, J. and KIKUCHI, E. 2009. The effects of particle surface texture on silk secretion by the caddisfly Goera japonica during case construction. Animal Behavior, vol. 77, p. 595-602. http://dx.doi. org/10.1016/j.anbehav.2008.10.027

OKANO, J., KIKUCHI, E. and SASAKI, O. 2010. The role of particle surface texture on case material selection and silk lining in caddis flies. Behavioral Ecology, vol. 21, no. 4, p. 826-835. http://dx.doi. org/10.1093/beheco/arq066

PES, AMO., HAMADA, N. and NESSIMIAN, JL. 2005. Chaves de identificação de larvas para famílias e gêneros de Trichoptera (Insecta) da Amazônia Central, Brasil. Revista Brasileira de Entomologia, vol. 49, no. 2, p. 181-204.

RUEDA-MARTÍN, PA. 2008. Morphología y biología de los estados inmaduros de Marilia cinerea y $M$. elongata, con redescripción del macho adulto de $M$. cinerea (Trichoptera: Odontoceridae). Revista de la Sociedad Entomológica Argentina, vol. 67, no. 1-2, p. 11-20.

WIGGINS, GB. 1996. Larvae of the North American caddisfly genera (Trichoptera). Toronto: University of Toronto Press. $400 \mathrm{p}$.

WIGGINS, GB. 2004. Caddisflies: the underwater architects. Toronto: University of Toronto Press. $292 \mathrm{p}$.

WILLIAMS, D. and PENAK, B. 1980. Some aspects of case building in Phryganea cinerea Walker (Trichoptera: Phryganeidae). Animal Behavior, vol. 28, p. 103-110. http://dx.doi.org/10.1016/ S0003-3472(80)80013-3

WILLIAMS, D., TAVARES, A. and BRYANT, E. 1987. Respiratory device or camouflage? - A case for the caddisfly. Oikos, vol. 50, p. 42-52. http://dx.doi. org/10.2307/3565400

Received: 02 December 2011 Accepted: 23 March 2012 